\title{
PERFORMANCE AND STRATEGIES TO DEVELOP WASTE BUSINESS
}

\section{Dika Anggari*)1, Ujang Sumarwan ${ }^{* *)}$, and Lilik Noor Yuliati**)}

*) School of Business, Bogor Agricultural University

Pajajaran Road, Bogor 16151

${ }^{* *}$ Department of Family and Consumer Sciences, Faculty of Human Ecology, Bogor Agricultural University IPB Darmaga Campus, Bogor 16680

\begin{abstract}
The objectives of this study are to measure the performance conducted based on the generating of turnover and magnitude of volume of wastes deposited by the waste sellers to CV. MBG and to analyze alternative strategies on waste business, especially for CV. MBG, through four perspectives on the Balanced Scorecard method. In addition, this study also analyzed the priorities of the four perspectives using ANP. The results show that the turnover per day can reach 94 million rupiah, and the volume generated per day can reach 12 tons. Furthermore, there are four perspectives that can measure the performance and internal process perspective as a priority to be more noticed. The conclusion of the research result shows that waste business becomes one of the most promising businesses. The managerial implication of this study is that the four BSD perspectives sorted according to their priorities from the ANP can be applied to support the company performance.
\end{abstract}

Keywords: performance measurement, waste processing, analytical network process, Balanced Scorecard, CV MBG

Abstrak: Tujuan dari penelitian ini adalah pengukuran kinerja yang dilakukan berdasarkan perolehan omzet dan besarnya volume sampah yang disetor oleh para pelapak kepada $C V$. $M B G$. Selanjutnya, menganalisa alternatif strategi pada bisnis sampah, khususnya pada CV. $M B G$, melalui empat perspektif pada metode Balanced Scorecard. Di samping itu, penelitian ini juga menganalisa prioritas dari empat perspektif dengan menggunakan ANP. Hasil penelitian menunjukkan bahwa omzet per hari bisa mencapai angka 94juta rupiah, selain itu, volume per hari bisa mencapai jumlah 12 ton, terdapat empat perspektif yang dapat mengukur kinerja dan perspektif proses internal sebagai prioritas untuk lebih di perhatikan. Kesimpulan dari hasil penelitian, menunjukkan bahwa bisnis sampah menjadi salah satu bisnis yang sangat menjanjikan. Implikasi manajerial dari penelitian ini adalah, keempat perspektif BSD diurutkan sesuai dengan prioritasnya dari hasil perhitungan ANP dapat diterapkan untuk menunjang kinerja perusahaan.

Kata kunci: pengukuran kinerja, pengolahan sampah, analytical network process, Balanced Scorecard, CV MBG

${ }^{1}$ Corresponding author:

Email: anggariedika@gmail.com 


\section{INTRODUCTION}

Traditional performance measurement is only conducted by viewing and comparing financial statements based on the existing history in which it gradually cannot be used anymore because the financial statements as performance benchmarks can no longer describe the strategic points of the company (Munifah, 2007). Several studies on performance measurements have been conducted in various industries, but no one has ever looked at the turnaround of activities and their performance results on a highly specific industry i.e. the waste industry.

One of the businesses in the field of waste is CV. Mohammad Baedowy Majestic Buana Group (CV MBG). Having been established for more than 10 years, the company has never had any assessments on its performance. In its journey, it must have experienced a lot of ups and downs; moreover, this business is moving in a very specific industry, which is not common in the people eyes i.e. the waste industry, where most people would assume that waste is the product in the last live chain which cannot be used anymore. Some people with an interesting personality are able to shake their brain and make waste as a door to business opportunities that can provide double income, and this notion was never thought before.

In fact, it should be realized that the waste is formed from the daily activities of humans and other living things, some of which have potential dangers present in liquid, mud, gas and manufactured products. Waste utilization, movement, and disposal are required so that the environment is not negatively affected (Williams, 2009). In addition, the increasing population and rapidly growing industrial growth will have an impact on the amount of waste generated such as wastes of plastics, paper, and packaging products containing B3 (Hazardous Toxic Substances) (Subekti, 2009). Wastes originating from settlements are generally very diverse, but in general at least $75 \%$ of them consist of organic waste and the rest is inorganic waste (Kurniawan, 2009).

In Jakarta alone, every day it produces wastes that accumulate with an overall weight of approximately $6,000-6,500$ tons. It is for sure that they give a lot of negative effects, namely, the risks of heavier pile and processing, amount of Tipping Fee up hundreds of billions of rupiah, and social cost for the citizens around TPST.

On the other hand, the amount of wastes that exceeds these estimates is actually very promising to be processed into money. If viewed from the perspective of entrepreneurship, these packaging wastes can be turned into a business area and have a great opportunity to develop. Business opportunity from waste processing business can start from small-scaled industries to corporate waste utilization. One of the businesses can be a transportation of waste disposal from a densely populated urban environment whose waste needs be cleared. Other opportunities from similar businesses can also be through the business of used goods in which some people think their goods are useless so they can sell them to those who need the goods with much cheaper value and prices. Moreover, there is a type of business purchasing the wastes which are then reutilized (e.g. using the municipal waste to be used as the raw material for the power plant). There is another type of business i.e. waste recycling business related to waste processing business that we often encounter. The last is the business of compost fertilizer most commonly known to have a high selling value. In addition, the compost fertilizers are beneficial to maintain environmental health and help plant growth. This supported research conducted by Handayani et al. (2009) in their research entitled "Study of Economic Value application of Recycling Concept at the Landfill (TPA) of Jatibarang, Semarang City". In fact, waste does have an economic value that at the end of it can generate income of billion rupiahs. In the previous research, the most profitable type of waste is a type of plastic waste that promises to generate turnover of Rp1,165,581,879,809.00 until 2025.

A large number companies are just relying on and trying to change and keep improving the concept of finance, but in fact, it is not only about the cost efficiency that should be improved. In reference to the Balanced Scorecard concept that will be used, there are three other factors that must be improved, namely, internal factor, customers, and learning and growth. Later, from the results of the grouping of the four perspectives on Balanced Scorecard, weighting is carried out and the results are prioritized by using the statistic tool that can accommodate the objectives, namely, Analytical Network Process. 
Making waste problem as a new economic source which is very possible must be socialized in Indonesia so that it can make business opportunity from related business wide open. In this case, Mr. Mohammad Baedowy as the owner of the company has already fully involved in this waste business; however, it will be better if the company conducts a performance measurement in order to sort out what should be improved or changed in the future.

There have been many articles or even researches raising the topic of waste processing that was studied from various sides, either from the analyzed technical field using NPV (Net Present Value) method, or from the agribusiness field which focused more on the effects of waste on the environment. Several previous studies such as Scortar et al. (2009) on "Household Waste Management Around the Globe", Sidarto (2010) on "Business Analysis of Household Waste Management Process with Cost and Benefit Ratio Approach to Support Environmental Hygiene", Misuzu Asari (2011) on "The Consumer Perspective on Household Hazardous Waste Management in Japan", Lindqvist (2013) on "Hybrid Governance": The Case of Household Solid Waste Management in Sweden ", and Aisyah (2013) on "Community- based Waste Management in Neighborhood Group at the RT 50 of Administrative Village of Sungai Pinang in North Samarinda District". The researches were conducted using the methods and points of view that are different from the academic background of each author; however, the core subject is to study the processing of household wastes that have been increasing and accumulating. In terms of economics, especially in terms of business that refers to performance, the research did not discuss and raise related topics in depth, but if investigated further, promising business opportunities are awaiting in this industry especially if you are able to run it properly. In fact, all from both organic and inorganic wastes can be turned into money, depending on the processing method. For example, the bones of chicken leftovers can be resold to be processed into animal feed and ceramics. The reality is happening in Bantargebang area in which the UMKM runs waste industry and is recognized to have a very promising turnover of billions of rupiah per month.

With various assumptions and learning from several related literatures, the research aims to know the performance measurement based on the earnings and the volume of waste deposited by the waster sellers to CV. MBG. Next, it analyzed alternative strategies on waste business, especially on CV. MBG, through the four perspectives on the Balanced Scorecard method. In addition, this study also analyzed the priorities of the four perspectives using ANP statistical measure.

The scope of this research is to focus on the waste collectors or waste middlemen who are in charge of collecting the wastes picked up by the previous scavengers, the partners who are willing to start a business in the related industry, and the employees and owner of the business engaged in the field of waste management and processing, namely, CV. MBG. Furthermore, the waste processed in this research is limited to plastic waste.

\section{METHODS}

This research used the primary data taken from the TPST Mustika Jaya Area i.e. from the CV. Majestic Buana Group located in Bekasi. The reason for choosing this $\mathrm{CV}$ as a research location was because this is a waste industry that is in its infancy or growing period. The research was conducted from December 2015 until March 2016.

This research was a case study based on the primary data obtained from interviews and questionnaires and was conducted with the waste collectors, partners, and SME employees engaged in the waste processing industry. This method was carried out to obtain accurate information on the flow in the waste processing chain, starting from the amount of production per day that the scavengers can collect. This plastic waste is sorted by the collectors and is processed by the company.

The samples of the research were obtained using interview technique and questionnaire filling where they sample were chosen and determined by the writer, and they were chosen purposively with certain considerations. The members of the research population came from three parts, namely, 1) Collectors or raw material suppliers, 2) Partners or those who buy the plastic shredder, and 3) Employees of CV. MBG or those who work for the $\mathrm{CV}$ either as fulltime employees or daily freelance workers that have different opportunities in their contribution as respondents. 
This research used quantitative descriptive analysis with reference to ANP (Analytical Network Process) model which is a further development of AHP (Analytical Hierarchy Process). Besides, it was assisted with the Balance Scorecard method. ANP method is able to fix the weakness of AHP method, which already existed earlier, with its ability to accommodate the interrelationship between criteria and alternatives. ANP also has two types of linkages, namely, the linkage in a set of elements (inner dependence) and with different elements (outer dependence), which makes the ANP method much more complex than AHP. The software that was used to process the ANP data was Super Decision 2.0.

The company strategy will be translated into an objective strategy with its Key Performance Indicators for the 4 existing perspectives (Vanany, 2003). The strategy of the design in applying the right business model by initiating the method through Balance Scorecard will result in three things, namely, Objective Strategy (on how an organization can run its operational activities for the achievement of organizational goals), Key Performance Indicators (KPI) (a set of measurement focusing on the most critical aspect of organizational performance for both current and future organizational successes) (Parmenter, 2010) and Strategy Map (as an illustration of causal relationship of objective strategies in each perspective).

Model Strategy Map is made to see the basis of causal relationships. Later, the leaders of organizations/ companies can sort out the next step to avoid failure that was previously existent. Designing a Strategy Map and value weighting can be said is an important step in designing BSC-based measurement system. Weighting needs to be done to see the comparison of objective strategies with KPI which means that it is increasingly important for the company to imply a more appropriate business model in the future, because the values of the objective strategy, KPI, and interests for its perspective are not the same. The result of weighting will be the weighted value for each objective strategy and the KPI in which the greater value indicates that it becomes a more important point to be chosen or implied or focused. Using this method can be the right choice because it is an approach that reflects the optimal solution as well as the overall business strategy.
After grouping the strategy map, it can be applied into the ANP application. The working of the ANP method is to use a network without having to set the level as in the hierarchy used in AHP. The main concept of ANP is influence, while that of AHP is preference. In the AHP network, there is a level of objectives, criteria, subcriteria, and alternatives where each level has elements whereas in ANP there are clusters that can have criteria and alternatives inside which are called nodes. In ANP method, there are two types of linkages, a) the linkage in a set of elements (Inner Dependence) which means there are elements in the same group/cluster; b) the linkage between different elements (outer dependence) which means elements in a different group/cluster is different by paying attention to each criteria to the method used. Therefore, it can be said that the ANP method is more complex than the AHP method. In this study, a number of variables were used and processed using the ANP method. The group or cluster in this study is a component of the business model, which in this case refers to the type, volume, human resources as well as its mechanisms, which eventually form a pattern in the ANP method.

In accordance with its basic principle, the main function of ANP/AHP is to structure complexity, measurement and synthesis. Furthermore, the decision-making stage with the ANP can be done in 5 steps as follows: model construction and problems; the formation of pair wise matrices matched from interdependent component levels, consistency ratio calculation, super matrix formation, and selection of the best alternative.

The theoretical framework of the research began with information that waste that is processed is certainly not the same as the waste that has not been processed because the economic value it contains can generate more promising income. With the turn of the business flow in the waste industry, the economic value is certainly not absolute, because it is based on the relationships that have been created before. But keep in mind that the business owner not only generates income but also maintains the balance of growth of the company. Therefore, performance measurement activities that can be operated through four perspectives are available using Balanced Scorecard method, which will be obtained by the objective strategy and KPI in each perspective i.e. customer perspective, internal 
process perspective, learning \& growth perspective, and finance perspective. After studying what happens with waste and all its recycling cycles with the BSC, the researcher needed weighting to see the priority scale among the four factors. The nature of ANP as a "network" can provide information on the relationship between one perspective and another one. The data obtained can be processed using the ANP or Analytical Network Process to know the results of the expected performance measurement which can be useful in the future. After the priority results were obtained, it is expected that the research results can be further enhanced by other researchers or implemented in the same industry. The theoretical framework of the research is described in Figure 1.

\section{RESULTS}

\section{Performance measurement based on the earned turnover and volume of waste deposited by the waste sellers to $\mathrm{CV}$. MBG}

In accordance with the objectives of the research i.e. to know the turnover per day, this chapter will discuss this turnover. Different raw materials have different economic values for their unit. There are 4 types of plastic processed by CV. MBG, namely, PET, PP, LDPE, and HDPE (Table 1).

If the total amount of wastes of the four types of plastics processed in a day was combined i.e. 12 tons multiplied by each economic value contained from the results, the total turnover per day from the processed plastic is about Rp94,500,000 excluding paying for operational costs and employee salaries (if using a paid wholesale system). Therefore, the daily volume of processed wastes generated can reach 12 tons for the four types of used plastic wastes.

Every day CV. MBG will purchase raw materials, which will be further manufactured into plastic, with a budget of Rp3,000,000 from its sellers in which the price of the 3,000 $\mathrm{kg}$ volume is $\mathrm{Rp} 3,000,000$ which is considered very cheap. The author had tried to find information from other entrepreneurs, and the business that just starts, the company will get a price of about Rp6,000,000-Rp7,000,000/ton. In connection with the above explanation of turnover, the volume of waste processing every day, at least in the number 12 tons for four types of plastic waste in use.

\section{Alternative strategy of CV. MBG through the Four} Perspectives on the Balanced Scorecard Method

The Balanced Scorecard concept was introduced by Kaplan and Norton (1996) who originally intended to measure performance in the business sector; however, along with the development of time, the concept of Balanced Scorecard was also developed so that it can be used as a measuring tool for public or non-profit organizations.

Balanced Scorecard concept was also involved in this research by detailing the four perspectives that is customer perspective, internal process perspective, learning and growth perspective, and financial perspective. Each perspective will be explained in detail in the discussion:

\section{Consumer Perspective}

In this case, more specifically, the customers refer to the collectors or sellers who interact with the CV. Majestic Buana Group. In accordance with the existing hierarchy in this waste industry, CV. Majestic Group will receive used goods especially plastic bottles from the collectors who have sorted the goods according to the specialization of the company, and these used bottles are then cut and ground into shredded plastic or even into plastic ores. The collectors collect the used goods from the people who scavenge or pick up all the trash on the streets in the form of cardboard, pieces of machine, or plastic bottles.

This perspective provides an overview of the definition of CV. MBG on the customer side. The product of this business is plastic or house of broom (lakop). The users of the product are bigger factories either in the country or abroad, because the shredded plastic supplied to a bigger factory can be made into more fine plastic ore, or it can be processed into ready to use plastic bottles while broom lakop is sold to the broom factory to be made into heads of ijuk brooms (broom of sugar palm fiber). The users of the products in the wider level are the public. It is then necessary to analyze the Consumer Perspective to identify the business objectives.

\section{Internal Process Perspective}

The internal process perspective is a set of processes within an organization or business line to create products or services according to customer expectations. In 
this perspective, it explains how business processes should be managed to deliver services and values to stakeholders and customers. Internal process perspective on the balanced scorecard CV. MBG is to emphasize how necessary it is to continuously improve the internal process.

\section{Learning and Growth Perspective}

The learning and growth perspective identifies the parameters that become the strengths of a company or organization. The function of this perspective is studied more deeply to give an idea of the capabilities of the CV. MBG to make changes by utilizing existing internal resources.

\section{Financial Perspective}

Literally, the financial aspect is said to be the most important aspect. The advance of a company is seen from how much turnover is generated, how much profit is earned, or how smooth its cash flow is. Of course, it cannot be blamed if success is measured from the financial side. However, remember that finances cannot "stand alone" without the help of other supporting aspects. Every organization or company has different ways of interpreting its financial perspective. CV MBG is more geared towards how to manage its finances effectively and efficiently, so it does not only focus on large profits.

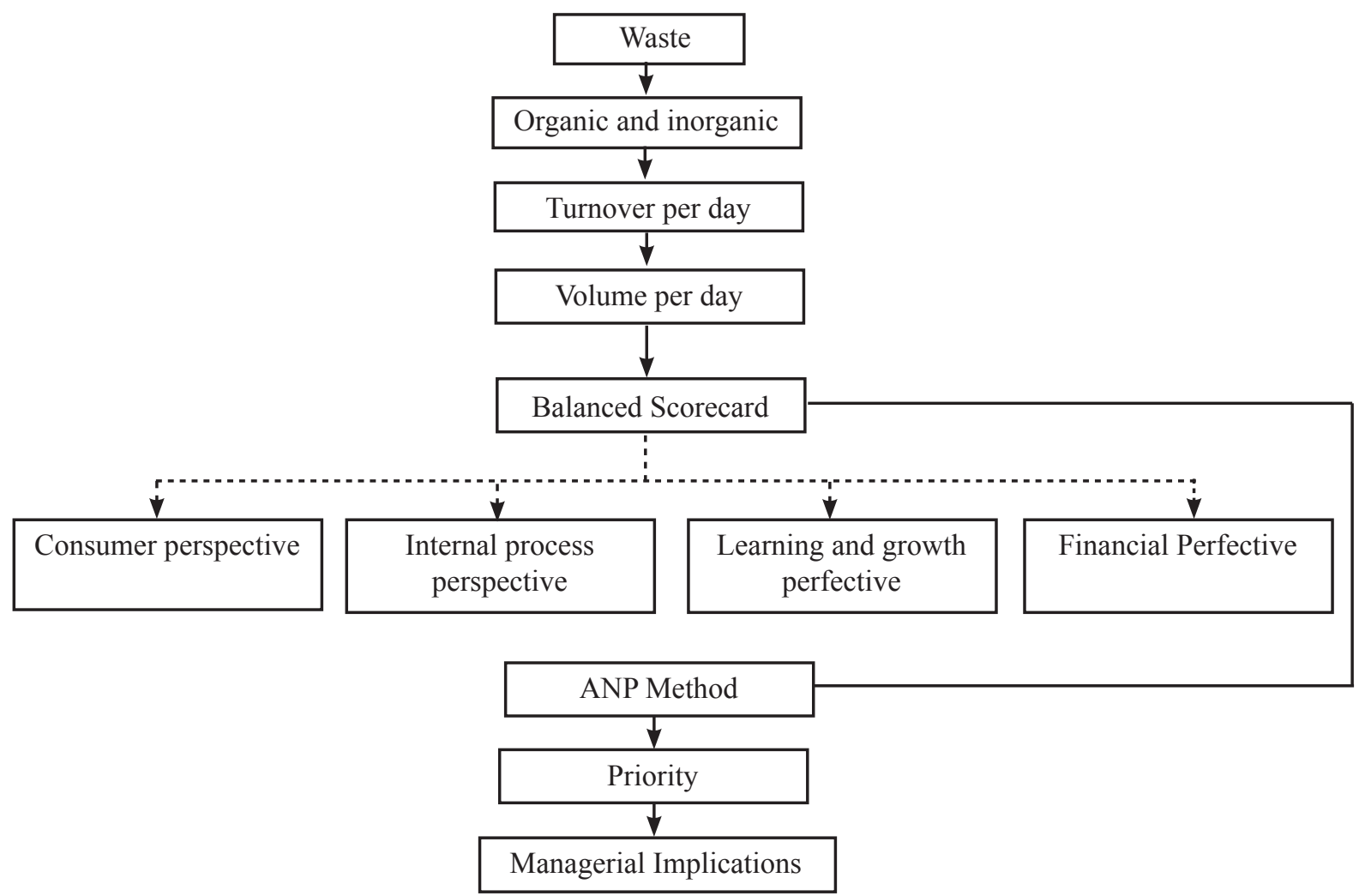

Figure 1. Research framework $(\longrightarrow$ Hierarchical relation; $\rightarrow$ Processed object)

Table 1. Calculation of plastic type turnover

\begin{tabular}{|c|c|c|c|}
\hline Type & Volume (Kg) & Economic Value & Turnover/day (Rp) \\
\hline PET & 3,000 & $6,500 / \mathrm{kg}$ & $19,500,000$ \\
\hline PP & 3,000 & $10,500 / \mathrm{kg}$ & $31,500,000$ \\
\hline LDPE & 3,000 & $7,500 / \mathrm{kg}$ & $22,500,000$ \\
\hline HDPE & 3,000 & $7,000 / \mathrm{kg}$ & $21,000,000$ \\
\hline Total & 12,000 & & $94,500,000$ \\
\hline
\end{tabular}




\section{The Objective Strategic Target of CV. MBG in the Balanced Scorecard}

The objective strategic target is the elaboration of the company vision and mission which is more specific and realistic so that there is a possibility that they can be achieved. Each point of the strategic objectives was obtained from the interviews with Mr. Mohammad Baedowy, the owner of the CV. Majestic Buana Group, in his office. With the elaboration of the objective strategy, the benchmarks can also be obtained which later will be useful for further analysis.

\section{Objective Strategy of the Consumer Perspective}

\section{Level of Trust}

Keep in mind that in running a waste industry, there is only 1 key i.e. trust. It has been proven that it is difficult to penetrate every layer that exists on this business. It shows that the foundation of a business line is that both sides start their business based on their mutual trust. For example, avoid cheating when weighing the waste to be deposited and sorted, and if any cheating in the form of water or stone in the heavy scale is revealed, the trust of one party is lost, thus causing the connection to be lost. Therefore, it takes cooperation to continue to foster a sense of confidence that business continues to run smoothly. The measure of the strategy target is the number of new sellers for the last 1 year and addition of new business partners for the last 1 year.

\section{Good Reputation}

A good big name becomes one of the reasons why many sellers or collectors are willing to deposit goods to the CV. MBG. No doubt, if they hear that CV. MBG have a lot of problems on various sides, bad reputation will spread in the community resulted in the loss of the willingness of the sellers to store his waste. Its impact occurs when no one wants to deposit waste anymore, and this can cause the business to go bankrupt since the first step of the actual money circulation is there. Target of the related objective strategy is to see how many sellers trust the company to deposit their goods. Therefore, the target size of this strategy is the total of sellers and partners who have become customers of CV. MBG.
Customer Satisfaction Level

Customers as the external public are the targets of public; therefore, communication should always be conducted to maintain and foster a harmonious relationship. This is due to the equal importance of both stable relationships with customers and internal public (Onong, 1989). In addition, this strategy is measured through the sellers who continuously deposit their wastes to CV. MBG and its partners who also repeat depositing their wastes in their stores.

\section{Objective Strategies of Internal Process Perspectives}

Employee Recruitment Quality

Qualified employees are surely influential on the undergoing business, thus recruiting qualified human resources will result in good business. There is no difficult requirement to join this industry; moreover, it can also be seen that its raw materials are easy to obtain with nearly zero capital. The target measurement of this strategy is only those who have the sincere intention and willingness and strong mental to perform in the fields. Throughout history, no one is able to become a businessman straightforwardly without experiencing the field filled with wastes

\section{Goods Sorting}

Goods sorting activity cannot be neglected, if there is a case of goods with different colors processed into the crusher machine, its sale value will drop significantly. The target measurement of this strategy is the volume of the goods in accordance with their respective types. In CV. MBG, there are four types of processed plastics; i.e. PET, PP, LD, and HDPE.

\section{Production and Operational Processes}

Production and operational activities must also be monitored to create alignment and balance within the company. The measure of this strategy is the large volume of wastes washed, made into broom, and shredded to be exported. 
Objective Strategy of Learning and Growth Perspective

Technical and Non-technical Training

What differentiates CV. MBG from other similar businesses is the form of training provided. For technical training, the owner does not hesitate to send his employees for 1-2 weeks to learn how to operate machines. Meanwhile, for non-technical training, the owner also comes to the site and visits to the field in case there are non-technical matters occur and hamper the business. The measure of target strategy is the duration and frequency of free training for 1 partner.

\section{Conducive Working Environment}

Fair and enjoyable working atmosphere can subconsciously improve the performance of its employees. Creativity can also be sharpened, and the target measure of this strategy is successful if the turnover rate is low. Consequently, this can be analyzed in terms of employee satisfaction level.

\section{Relationship with Surroundings}

One of non-technical factors considered to be trivial yet fairly decisive is the relationship with the surrounding environment. A special approach is needed to convince the local people to maintain the business without harming both parties. The target measure of this strategy is to obtain permission from the chairman of the neighborhood, and to receive indirect permission from the local people.

\section{Overseas and Out of Town Marketing}

Conducting business in the waste industry is fairly productive. It is evident from the success of CV. MBG which not only sells shredded plastic domestically but can also exports its products to China. Its measure of target strategy is the amount of volumes that can be sold in domestic market and exported overseas.

\section{Objective Strategy of Financial Perspective}

Financial Order

Financial order should be highlighted as the continuity of administration becomes one of the benchmarks of success in a business. Although business in this industry can be classified into small and medium enterprises, financial order should be conducted. The measure of this strategy target can be assessed when CV. MBG has basic financial statements in the forms of profit and loss statements, cash flow statements, and budget reports.

\section{Investment}

In business, expertise is necessary to conduct financial aspects carefully and thoroughly. One of the attempts is to rotate funds by doing investment. A range of benefits can be obtained from investing effectively; for instance, some machines utilized in the factory are not all purchased as a few of them are rented in order to save costs. The measure of this strategy target is the type of investment performed by CV. MBG.

\section{Economic Value per Unit}

Waste has recycling potential, and as this potential is recognized, the economic value of the city wastes can be obtained; therefore, it can provide economic benefits (Laili et al. 2006). The measure of this strategy target can be calculated from the economic value per product obtained from the waste processing to be re-sold outside.

\section{Four Perspective Priorities of CV MBG and ANP}

The weighting on the objective strategy aims to determine the contribution level of each Balanced Scorecard perspective and that of each objective strategy (Suhendi, 2012). The ANP (Analytical Network Process) tool functions to help determine the priority scale of all four perspectives on the Balanced Scorecard (Figure 2). The data collection was conducted by using Super Decision software version 2.0 Beta developed by Thomas, L. Saaty. The results show that the internal perspective has the highest necessity by 0.340521 and becomes the main priority. In the second priority, there is the learning and growth perspective with a value of 0.289359 . The third priority is the financial perspective with a value of 0.186565 . Meanwhile, the lowest priority is the customer perspective with a value of 0.183557 .

\section{Priorities on Each Strategic Target Perspective}

\section{Customer Perspective}

In the customer perspective, there are three objective strategies; i.e. Level of Trust, Good Reputation, and Level of Customer Satisfaction. The weighting results 
on ANP indicate that the objective strategy of Good Reputation contains the highest value of 0.378736 compared with Customer Satisfaction with a value of 0.370486 and a Trust Rate of 0.250776 .

\section{Internal Process Perspective}

In the internal process perspective, there are three objective strategies; i.e. Employee Recruitment Quality, Goods Sorting, and Production and Operational Process. The weighting results on ANP indicate that the objective strategy of Employee Recruitment Quality contains the highest value of 0.473393 compared with Production and Operational Process with a value of 0.327283 and Goods Sorting of 0.199324 .

\section{Learning and Growth Perspective}

In the learning and growth perspective, there are four objective strategies. The weighting result in ANP indicates that the objective strategy of conducive working environment has the highest value of 0.365049 if compared with the Relationship and surrounding Environment with a value of 0.270701 , Technical \& Non-Technical Training with a value of 0.199039 , and Overseas Marketing of 0.16521.

\section{Financial Perspective}

In the financial process perspective, there are three objective strategies; i.e. Financial Discipline, Investment, and Economic Value per Unit. The weighing results on ANP indicate that the objective strategy of Investment contains the highest value of 0.424589 compared with the Financial Order with a value of 0.29108 , and Economic Value per Unit of 0.28433 .

\section{Overall Strategic Target Priorities}

Balanced Scorecard concept is a strategy management system by transforming the company's visions and missions into a framework model by exploring the four important perspectives. Each objective strategy is weighted to be examined by using statistical tool; i.e. Analytical Network Process, or ANP. The overall weighting results are presented in Figure 3.

In general, Employee Recruitment Quality plays the most important role as it obtained the highest weight value compared with other factors.

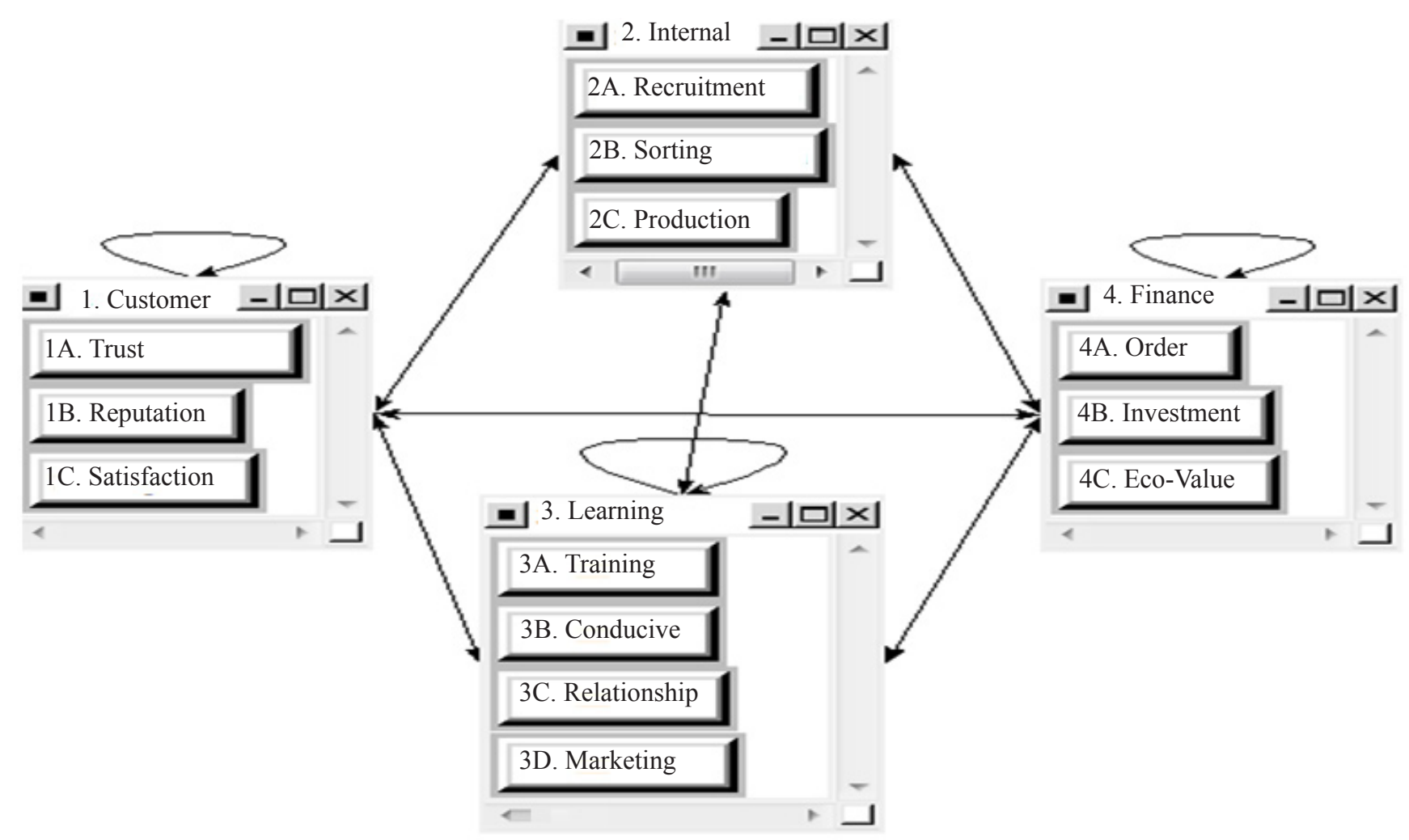

Figure 2. Framework of four perspectives in using balanced scorecard 


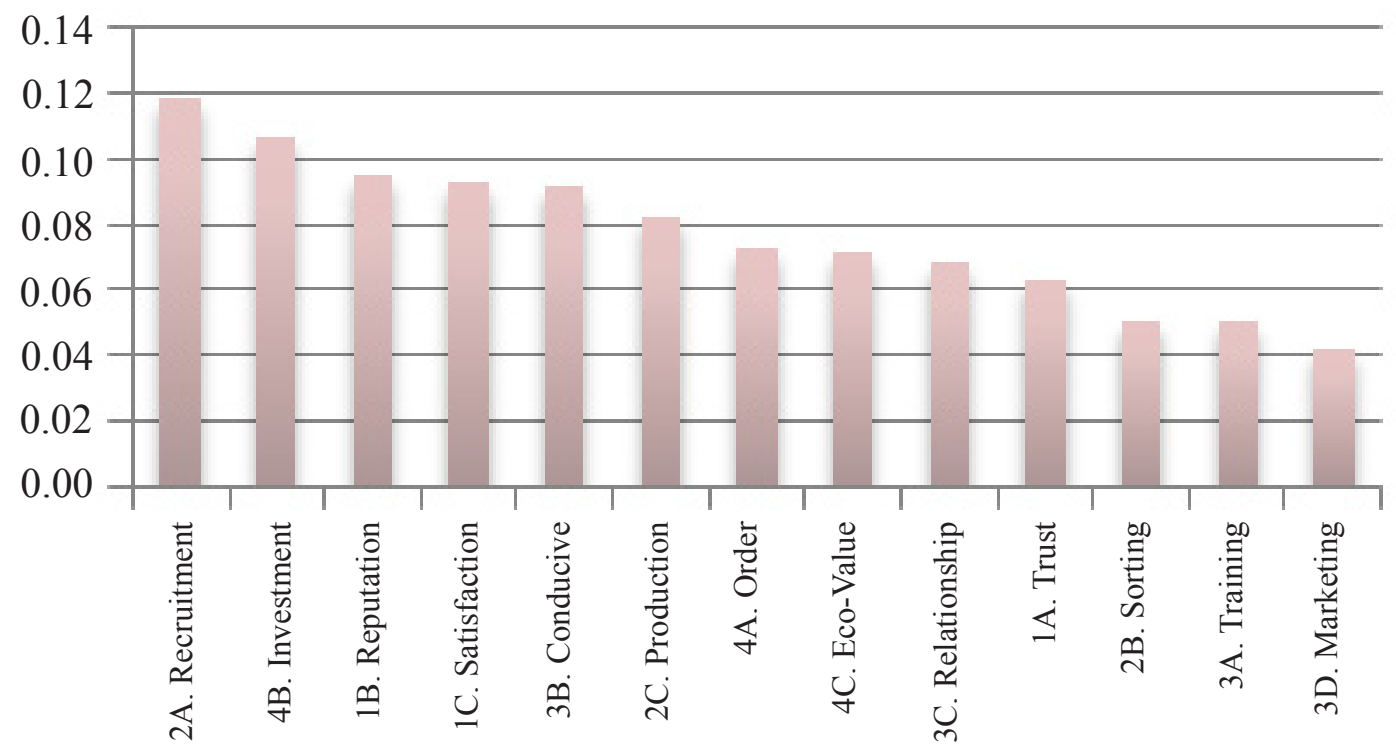

Figure 3. Overall weighing of objective strategy

\section{Managerial Implication}

The established Balanced Scorecard framework is a reflection of everything that exists atCV.MBG. Objective strategy was obtained through interviews with experts conducted through studies on the four perspectives. In the future, the function of Balanced Scorecard is not only as an assessment but it can also be used as input for better condition of the company; therefore, it needs socialization and deep understanding, and the results will be conveyed to the stakeholders of the company including employees, partners and waster sellers. After being studied more thoroughly, this Balance Scorecard is actually very important because the company never applied this before. Besides using BSC method in the research, the writer also applied weighting using the statistical tool of Analytical Network Process so that the two methods could create a number of managerial implications. One result of the comparisons of the four perspectives of the Balanced Scorecard is that internal process perspective is the top priority followed by learning and growth perspective, financial perspective and customer perspective with the least weight.

The function of the ANP measuring instrument as weight grouping gives an idea that from the overall performance measurement results, there is a sequence of perspectives that must be improved for future performance measurement. The concept of this study leads to performance measurement, which was done to improve or provide inputs and suggestions to $\mathrm{CV}$. MBG so that it is able to improve the performances of all human resources involved. The first priority gives the result that there should be a need to change and try to improve the quality of performance. The less value indicates that no change can be performed, and this perspective is a major contributor in the progress and improvement of performance of CV. MBG.

\section{CONCLUSIONS AND RECOMMENDATIONS}

\section{Conclusions}

From the research results, there is one basic thing that can become information for a creative society i.e. a waste business that promises to be implied. Turnover as high as a mound of waste waiting to be excavated is referred to the research I did in CV MBG, and the amount can be in the range of Rp94,000,000. Business waste can be said to be a 'cheap' business but not 'cheap'. In fact, in general, raw materials are available everywhere, and they tend to be something that most people throw away, but the generated turnover can be very promising. Meanwhile, the volume of waste that can be processed per day reaches 12 tons. The amount is very large for business size. The four types of plastic waste were processed to produce 12 tons of shredded plastics. Moreover, these 12 tons come from the 3 tons of each type of waste using the crusher machine. Due to its limitations in employees and location of work, the company can invest in one machine only. Based on the results of the analysis using the Balanced Scorecard, there are four perspectives, each of which 
has an objective strategy and KPI. There are a total of 13 objective strategies consisting of 3 strategies on the customer perspective, 3 strategies on the internal process perspective, 4 strategies on the learning and growth perspective and 3 strategies on a financial perspective.

In this research, Analytical Network Process method was used to obtain weighting. ANP processing result shows that first priority is internal perspective with a weight value of 0.340521 . The second priority with a value of 0.289359 is learning \& growth perspective. The third priority level is financial perspective with a value of 0.186565 . The lowest weight is the customer perspective with a value of 0.183557 .

\section{Recommendations}

A number of recommendations can be submitted to the company and for the completion of similar research in the future include the requirement of a special team to socialize the balanced scorecard, and to increase awareness of the top officials of the company to be willing to implement the balanced scorecard method periodically. In addition, another special team is required to understand the ANP and to imply the results of the research conducted periodically. More attention should be given to internal perspective, and the company owner should have closer relationship with the employees. Moreover, it is expected that in the future researches, researchers can perform studies using other statistical tools.

\section{REFERENCES}

Aisyah. 2013. Pengelolaan sampah rumah tangga berbasis masyarakat di RT 50 Kelurahan Sungai Pinang dalam Kecamatan Samarinda Utara (Tinjauan Peraturan Daerah Kota Samarinda Nomor 02 Tahun 2011 Tentang Pengelolaan Sampah). Jurnal Beraja Niti 2(12): 1-8.

Handayani DS, Budisulistiorini SH, Nuraini MR. 2009. Kajian nilai ekonomi penerapan konsep daur ulang pada TPA Jatibarang Kota Semarang. Jurnal Presipitasi: Media Komunikasi dan Pengembangan Teknik Lingkungan, 6(2): 3544. doi:http://dx.doi.org/10.14710/presipitasi. v6i2.35-44
Kaplan S, Norton DP. 1996. Balanced Scorecard Menerapkan Strategi Menjadi Aksi. Alih Bahasa R. Yosi Pasla, Judul Asli : The Balanced Scorecard: Translating Strategy into Action. Boston, MA: Harvard Business School Press.

Kurniawan N. 2009. Analisis kelayakan pengolahan sampah kota menjadi produk yang berguna di TPA Bantargebang. Depok: Universitas Gunadarma.

Laili FM, Rachmawati S, Ningrum AV. 2006. Pemberdayaan potensi ekonomi sampah kota surabaya penyuluhan pengelolaan sampah terintegrasi di Lingkungan Keputih Surabaya. Surabaya: Institut Teknologi Sepuluh Nopember.

Lindqvist K. 2013. Hybrid governance: the case of household solid waste management in Sweden. Public Organization Review 13(2):143-154. https://doi.org/10.1007/s11115-013-0229-8.

MisuzuA, SakaiShin-ichi. 2011. ConsumerPerspectives on Household Hazardous Waste Management in Japan. 3R International, Kyoto Workshop on $3 R$ and Waste Management. Kyoto University Environment Preservation Center, Yoshida.

Scortar L, Lazar S, Suciu L. 2009. Household waste management around the globe in Managerial Challenges of the Contemporary Society. Proceedings; Cluj-Napoca : 249-256. ClujNapoca: Babes Bolyai University.

Munifah. 2007. Analisis pengukuran kinerja perusahaan menggunakan metode Balanced Scorecard (BSC) dan Analytical Hierarchy Process (AHP) di Pabrik Gula Gending Probolinggo. Jurnal Ilmiah Teknik dan Manajemen Produksi “TEKMAPRO” 2(2): 1-6.

Onong U, Effendy. 1989. Human relations dan Public Relations dalam Management; (Edisi Ketujuh). Bandung: Mandar Maju.

Parmenter D. 2010. Mengembangkan Mengimplementasikan dan Menggunakan. Alih Bahasa Hauriyan, Judul Asli : Key Performance Indicators - Developing, Implementing, and Using Winning KPIs;(Sec Ed). New Zealand, PPM.

Sidarto. 2010. Analisa usaha proses pengelolaan sampah rumah tangga dengan pendekatan cost and benefit ratio guna menunjang kebersihan lingkungan. Jurnal Teknologi 3(2):161-168.

Subekti S. 2009. Pengelolaan Sampah Rumah Tangga 3R Berbasis Masyarakat. Majalah Ilmiah 
Universitas Pandanaran 7(14): 1-6.

Suhendi. 2010. Perancangan sistem pengukuran kinerja MB - IPB dengan Metode Balance Scorecard [tesis]. Bogor: MB-IPB.

Vanany I. 2003. Aplikasi Analytic Network Process (ANP) pada perancangan sistem pengukuran kinerja (studi kasus pada PT.X). Jurnal Teknik Industri 5(1):50-62.

Williams B. 2009. The Management of Household Hazardous Waste in Harris County: Residents Attitudes and Perceptions. Texas Southern University. 